UDC 336.24:005.21:550.389.2:061.1€C

DOI https://doi.org/10.32836/2308-6971/2019.1.3

\title{
DIVERSIFICATION OF STRATEGIC PROGRAMS FOR THE TRANSFORMATION OF CUSTOMS AFFAIRS IN THE UKRAINE: A KEY TO IMPLEMENTATION OR A DESTRUCTIVE PERSPECTIVE
}

Customs activity is the object of social interest in the Ukraine. Stakeholders and those who are interested in discussing of ratings, the formation of the image of the customs support the level of these interests. In the article the conceptual questions of implementation and fulfilment of andestandings on customs affairsof the Association Agreement with the European Union, the state of their fulfilment, as well as the main emphasis of the presented strategies of reforming the state customs affairsare considered. The conclusions of the monitoring of the fulfilment of the Association Agreement, the expert examinations of public organizations, and data from international trade statistics provided the grounds come to the conclusions that the search for an optimal strategy is not a period of time, but only a professional approach, moderation of goals, synergy of desire and the participation of state institutions in satisfaction of public expectations.

The paper concludes that an in-depth analysis of the causes and consequences of overcoming the accumulated uncertainties and inconsistencies in the development of the state customs affairs, which require immediate intervention, is possible if the persons who have experience and professional competence in customs affairs, professional competence and a high level of social and political culture will be involved in whole chain of stakeholders of national customs affairs. This will solve the problems faced by the world's customs administrations and Ukraine respectively, propose the goals and identify the ways to achieve them in the shortest possible time with minimal resource capacities and costs, and effective means of providing them.

Purposely well-founded presentation of materials in the article, dialectical, systematic, deductive methods of research were used, which gave a more complete understanding of the institutional processes taking place in the customs sphere.

Key words: Strategy, Strategic Goals, State Customs Affairs, Reforms, Transformation, Monitoring, Expertise, Community.

JEL Classification: K23.

Iryna KVELIASHVILI, University of Customs and Finance, Ukraine

\section{Introduction}

The long period of institutional transformation of the State Fiscal Service of Ukraine has gained a vision of a steady and endless perspective of the process. Business and society, which are participants in the triad of strategic transformations and reorganization of the format of perception of the Ukraine in the external space, have actually become hostages of strategic innovations without reaching the ultimate goal, which was declared by each of the presented strategies.

Unlike the others, in this state institute was quite frequent in a short period of time the reorganization and restructuring, which did not provide a constructive impetus for its development, and as it has already been recognized, caused significant damage and created the basis for the stagnation of customs processes and transformations in the country. 
The process in the cource of which the social goals adapt to the goals of the organization, is not based on a comprehensive analysis or thought. Rather, it affirms to the fact that the postulate, which has not been verified by anyone, but repeatedly prevails over precise thinking. About this it is appropriate to say the classic of institutionalism Douglas North [1].

Determination of the mission of State Fiscal Servicein the presentation of one of the latest development strategies in the period up to 2020 [2] is a confirmation of this process. The philosophy and purpose of the mission is to weighed determine the values and principles of organization, to identify the interests and expectations regarding the interaction of the organization with the surroundings and stakeholders.

The mission of the Ministry of Finance of Ukraine, under the making subordinate of which is the State Fiscal Service, consists in financially security the fulfilment of state functions on the basis of the weighed budget policy, creating the conditions for stable economic development by means of public finances management in accordance with the principles of balance, efficiency, impartiality, integrity, stability and transparency.

With its mission for the period up to 2020, the State Fiscal Service identified and quoted the main tasks assigned by the government to the service - administration of taxes, fees, customs duties and a single contribution to compulsory for everyone insurance, providing quality services to taxpayers, facilitating to international trade and entrepreneurial activity. That is to say, exclusively fiscal goals are declared.

While it is believed that the primary values and principles of State Fiscal Service activity are still a transparent and impartial institutional process that, under primary conditions, ensures the national interests and security of the state in the economic internal and external surroundings.

Formalism, as a state of activity, can be observed on the example of chronology and diversification of strategic goals and initiatives in the presented projects of the customs affairsreformation in the Ukraine in accordance with the conditions stipulated by the Association Agreement with the European Union [3].

Douglas North determined the criteria for evolutionary models, which represent a combination of constancy (inheritance) and change. There must be both immutable and variable elements, and even the changing element itself must be inherited if we are talking about the system as evolutionary [1].

That is, perceiving the postulate of the classics regarding the variability and invariabilityof elements of change through extrapolation to the processes of transformation in the customs sphere, an important condition is the mild convergence of innovations with achievements that support the quality of activity and the stable development of the reform object. In our case - the state customs affairs of the Ukraine.

Literary review. Since the enactment of the Decree of President on the creation of the own customs affairsin the Ukraine, scientists whose sphere of interest was related to the economy, international relations, public administration, management, and others, they conducted research and, in their writings, tried to find ways and methods for the development in the country intellectual and resource-able state institution. The most cited scientists are considered Grebelnyk O.P., Dubinina A.A., Dorin F.L., Kivalov S.V., Kozyrin A.N., Sandrovkyi K.K.

The development of scientific views with the formation and development of customs affairsin theUkraine is connected with the names of such scientists as Berezhniuk I.G., Ivashova L.M., Lypovska N.A., Pashko P.V., Pysmennyi I.V., Pryimachenko D.V., Chentsov V.V. and many others.

The current status of the state customs affairs is in a phase of stagnation and needs 
- synergistic efforts of scientists, practitioners to overcoming and worthy transition in the period

- ofconstant development.

The purpose of the study consists of differentiation of content-presented strategic projects and programs for the transformation of the state customs affairs and the conditions under which their effective introduction is possible.

Methods of research.Purposely well-founded presentation of materials in the article, dialectical, systematic, deductive methods of research were used, which gave a more complete understanding of the institutional processes taking place in the customs sphere.

2. Relevance of the strategic goals of the transformation of the customs affairs in the Ukraine to the issues of customs reform as stipulated by the EU-Ukraine Association Agreement

The beginning of the active period of the presentations of customs reforms may be 2015 . That is, the next after the creation of the State Fiscal Service, reorganized from the Ministry of Income and Charges of the Ukraine.

Already in 2015, the largest coalition of the leading public organizations and experts from the Ukraine who united for the promotion and implementation of reforms in the Ukraine to the association "Reanimation Package of Reforms", have been conducted an analytical work "Institutional problems of the Ukrainian tax system and ways of their solution" [4].

Problems in the field of customs relations, defined in the analytical work, concern issues that have been relevant for a long time, needed to be highlighted and resolved, search for ways to improve and / or avoid, and consist of:

1. High volume smuggling and "gray" imports.

2. Non-compliance with EU standards for customs clearance of goods (existence of queues, use of a greater amount of time during customs clearance in comparison with EU standards).

3. Groundless adjustment of customs value by the customs authorities and unfounded refusal by the customs authorities in cases of determining the customs value by other methods, which exceeds the corresponding indicator in the EU countries).

4. An automated system of risk management during the customs clearance of goods and vehicles that does not meet the requirements of the Kyoto Convention on Harmonization and Simplification of Customs Procedures. The main thing is that the system should be open.

5. Practical absence of the use of postaudit control methods, which in turn are one of the fundamental components of the customs affairs.

6. Presence of cases of unwarranted detention of goods due to interference with the work of customs authorities of state bodies with law-enforcement functions (Security Service of Ukraine, Ministry of Internal Affairs, etc.).

7. Lack of practice of making personal accountable in case of unlawful decisions making, actions or inactivity of officials of customs authorities of all levels.

8. Fulfilmentof the functions of control by the customs authorities over compliance with state standards, that is not inherent to them.

Customs issues and issues of encouragement of trade are laid down in the priority tasks of execution of the Association Agreement with the EU. According to the agreements about $70 \%$ of the norms of the customs legislation of Ukraine should be implemented to the provisions of the EU Customs Code. 
In the conclusions of the International Center for Advanced Research, in the analytical collection "Reforms in Ukraine: Expert Examination of the Passed Governmental Decisions", in 2015 [5], the main tasks to be realized during the realization of the customs reform are identified as follows:

- Simplification of customs procedures and automation of customs affairs;

- Reduction of time spent on customs clearance of goods;

- Development of a mechanism for providing public assessment of the officials of the customs authorities by the business community and the public representatives;

- Introduction of an effective system for the exchange of information among customs authorities and companies;

- Creation of customs postaudit units in the structure of customs authorities and strengthening the role of the main direction of the activities of customs authorities;

- Creation of a system of rapid response in cases of violations within the limits of customs work;

- Ensuring of effective conduct of "public control";

- Taking measures as regards to non-admission and preventive measures of the manifestation of corruption among the customs officials.

The questions that need to be improved and resolved, and those to be included during the reform of the customs affairs, are practically identical and differentiate according to the categories of attention: legal, organizational and structural, technological and communication. Proceeding from this, a hierarchy of goals, which is determined by the mission of the state institute, must be formed, and the strategy for development is defined.

Government projects are created specifically to improve customs activities and their adaptation, increase the level of quality to the international, and which were presented to the public since June 2015, had the following emphases.

Draft Institutional Reform of the State Fiscal Service, has been presented on June 24, 2015 in the video conference with the territorial authorities of the State Fiscal Service.

The strategic objectives of Institutional Reform have been established the following: the increase of the level of population confidence concerning the activities of the income and duty bodies and supervisory bodies, one of the ways is the elimination of corruption at all levels of the State Fiscal Service, structural changes, and new personnel policies; modernization of tax and customs control, high-quality and efficient tax administration, which should be achieved through modernization of control mechanisms, increase of productivity and efficiency of State Fiscal Serviceactivities.

The achievement of strategic goals, in the understanding of the authors of the concept, should take place through:

1. Transition of the State Fiscal Serviceof the Ukraine into subordination to the Ministry of Finance of Ukraine.

2. Growth from 2 to 5 positions of deputy heads ofState Fiscal Serviceof the Ukraine.

3. Reduction of the number of departments in the State Fiscal Serviceof the Ukraine in order to optimization of the functions, structure of the central apparatus.

4. Introduction of KPI (key performance indicators) for State Fiscal Serviceand its leaders, optimization of management processes.

5. Increase of the effectiveness of preventing corruption;

6. Increase of the efficiency of tax and customs control; 
7. Introduction of high-productive tax administration system. [6]

Strategic goals are also defined by a number of state legal acts that provide the putting into effect of the measuresfor the transformation of customsactivities.

The agreement on the Coalition of deputy factions "European Ukraine" [7] provides for "a significant reduction in the number of the State Fiscal Service", the transformation of the tax control model with a waiver from punitive to service, which includes the establishment of personal financial responsibility of tax and customs officials for their illegal actions or inactivity, which led to losses of subjects of entrepreneurial activity.

Regarding state programs on customs affairsreform, the Strategy for Stable Development "Ukraine-2020" [8] has been identified the implementation of the reforms of the state customs affairs and integration into the customs community of the European Union, as an integral part of the country's development vector.

Plan of measures to fulfilment the program of the Cabinet of Ministers of Ukraine and the Strategy "Ukraine-2020", including items on "a significant reduction in the number of employees of the State Fiscal Service"; establishment of personal financial responsibility of tax and customs officials for losses incurred by business entities through illegal actions or omissions of officials.

In 2016, the idea of depriving customs of the status of legal entities was presented and supported by the International Currency Fund, but the registered bill "On National Customs" was not adopted.

In the continuation of customs reforms, the Minister of Finance announced conditions that, in order to bring the organizational structure of the State Fiscal Service to a functional principle, it was necessary to change it substantially, but it still needs radical improvement [9].

By means of Order of the Cabinet of Ministers of Ukraine dated February 11, 2016 No. 267-p [10] has been approved the Concept of involvement of companies (advisers) in the reformation of State Fiscal Service customs. The purpose of the Concept is to carry out reforms of the State Fiscal Service customs authorities, guided by the Customs prototypes of the EU as the main reference point for customs cooperation between Ukraine and the EU.

For its realization it is envisaged to involve an international company (advisor) with successful experience in the reform of customs authorities in European countries for the consultation of the State Fiscal Service on issues related to the reform of customs authorities. Realization of such Concept will enable: to increase the volume of revenues to the state budget of customs payments, to minimize the possibility of corruption by customs authorities, to strengthen the institutional capacity of customs authorities within the bounds of their main tasks, to simplify customs procedures for enterprises. Its realization and performance is planned for two years.

As part of the customs reform, at the end of March 2017, the Concept for the reformation

of the customs direction of the State Fiscal Service was approved, which was prepared by the Ministry of Finance, taking into account of recommendations of Internal Currency Fund, EU customs standards and recommendations of the US Customs and Customs Border Service [11].

To implement the Concept, the Ministry of Finance has drafted the Project ofPlan of Customs Reform Action for 19 directions of EU customs standards that will implement changes. Each direction clearly describes the list of measures necessary for the implementation of the customs reform, which specifies: specific dates, responsible bodies and clearly identified acts that need to be elaborated or to be amended in order to achievement of the indicated tasks.

An unexpected and unanticipatedit looked like a suggestion to create Interregional Customs and the Main Interregional Department of the State Fiscal Service. Territorial and energy cus- 
toms were planned to be attached to the Interregional Customs with the deprivation of the status of an independent legal entity.

In early 2018, all initiated initiatives were canceled by the Cabinet of Ministers of Ukraine.

In the general sense, the tendency of state initiatives regarding the top-priority actuality of the organizational and structural and personnel reforms is traced. Questions about the customs affairs related to the implementation of customs procedures that require transformation are transferred to the out-sourcing area.

Thus, Ukraine's customs reform is still in a state of uncertainty and inconsistency, which in turn does not contribute to the declared goals and postpones their achievements for an indefinite period of time.

Uncertainties are an integral part of the decision-making process within the framework and in the process of public administration, have a significant influence on the processes and results of the adoption of management decisions, is a real and inevitable factor in the projection, programming, adoption and implementation of such decisions in many situations in pursuance of the realization of government administration [12].

Social expectations, as described by the well-known in the field of competitive strategies, Michael E. Porter [13], reflect the impact on the organization of such factors as state policy, social relations, social morality, and much more. These four elements must be taken into account when working out real and easily feasible complex of goals and means.

Porter identified and suggested test accents for the chosen goals and means on their coherence and adequacy of the competitive strategy by the following criteria: internal consistency; compliance with the surroundings; conformity to resources; communication and realization.

The testing of strategies for the development and reformation of the state customs

affairs, presented to the public in recent years, has no opportunity to provide adequate positive statements about the attainability, actuality, timeliness and, in principle, the need for such reforms to be implemented.

So the uncompromising approach to Porter's test questions regarding the coherence and adequacy of strategic goals can provide an answer to the question of the viability of strategic manifestos.

Strategic goals are defined for the long-term period. Bodies of state powerelaborate intermediate and tactical goals, and if necessary, a system of interconnected tactical objectives can be developed, the consistent implementation of which contributes to the achievement of the ultimate strategic goal [14].

As Michael Jordan argues, all stakeholders should know that improvement has a price point of view in expendituresof political and economic resources. But over time, sustainable development can be a compensator for these expenditures by means of expansion of the political and economic opportunities that are available to the public and will spread to public administration leaders [15].

Understanding the ultimate strategic goal is to achieve the planned transformations and reforms. And if we proceed from the conclusion that Ukraine's exit into the external market is, above all, the image and advantages of membership in the World Trade Organization, the World Customs Organization, integration with the EU, execution of the principles and rules of partnership, the same has all the primary emphasis in processes relating to development of customs affairsand customs activities.

The most important three main goals of Ukraine's trade development over the next five years are defined in the export strategy developed by the Ministry of Economic Development and 
Trade of the Ukraine with the support of the International Trade Center, which is a joint agency of the World Trade Organization and the United Nations Organization [16]:

No 1 Creation of the conditions for stimulating the sphere of trade and innovation in order to diversification the export of Ukrainian goods and services.

No 2 Development of business and trade support services that can increase the competitiveness of enterprises, in particular small and medium enterprises.

No 3 Increasing of the level of knowledge and skills, required by enterprises for international trade.

The identified goals have the right to be extrapolated and appropriate for a promising "import" strategy. The diversification of the import nomenclature requires the moderation, on the one hand necessary for the introduction of innovative technologies and programs, on the other - the need for comprehensive support for the development of national commodity

producers, legal business and lawful trade.

On this occasion, it should be noted that the current EU Customs Code [30] has defined the mission of customs administrations as overseeing the international trade of the Union, thereby promoting fair and open trade, the implementation of external aspects in the internal market, and so on, with their responsibility for this.

All measures of the EU customs administrations are aimed at protection the financial interests of the Union and its member states, protection the Union from unfair and unlawful trade, supporting legitimate business activities, ensuring the safety and security of the Union and its inhabitants, and protecting the environment, where appropriate, in close cooperation with other authorities; maintaining a proper balance between customs control and promoting legitimate trade.

The protection and security functions, as you can see, are considered as the top priorities, although the presence of them is seen, but not the basic, both fiscal and service functions of customs administrations.

On the basis of these tasks it is important to form measures for the reform of the state structure, which is intended to provide, within the limits of its competence, responsibility for the implementation of customs affairsin the country.

The lack of a single conceptual vision of the reformation of the national customs affairs indicatesthe imperfection and incompleteness of initiatives, the lack and insolvency of an administrative resource for their implementation.

\section{Monitoring as an indicator of the stagnation of the state customs affairs at the present} stage

The Strategic Indicators for the implementation of the Strategy Ukraine- 2020 provide for the achievement of $25 \mathrm{key}$ indicators by means of which it is possible to assess the progress of the planned reforms and programs. The strategy stipulates that "exercise of normative legal and organizational support for its realization consists in the development and adoption in accordance with the prescribed manner of the necessary normative-legal acts, annual action plans for its conducting and monitoring of their execution state."

That is, monitoring is recognized as one of the instrument of power control, the fulfilment of obligations declared by the Strategy in the area of responsibility of the authorities, business, civil society.

The Government Office for European and Euro-Atlantic Integration, together with the Ministry of Justice of Ukraine, has developed a system for monitoring and evaluating the effective- 
ness of the Agreement through the development and operation of unified complex information and analytical system that contains information on tasks for the execution of the Agreement, their state of execution and evaluation of the effectiveness of the implementation of the Agreement [17].

If the report on the status of fulfilment of the obligations of the Agreement in 2016 identified the primary actions and steps for the implementation of the planned measures, then according to the results of work in 2017 on customs matters and trade facilitation, the state of their implementation will be specified.

During 2016 the Ukraine was supposed to fulfill two obligations in the customs sphere:

1. To establish a single electronic system for the exchange of data on goodsmoved by transitprovided for by the Convention on a single transit regime dd. May 20, 1987;

2. To introduce a united administrative document that will be used for the procedure of joint transit, import or export - is provided for by the Convention on Facilitation of Trade in Goods of May 20, 1987.

According to expert estimates, as of November 1, 2017, implementation of obligations to simplification of customs formalities almost did not take place.

The Verkhovna Rada of Ukraine was supposed to adopt framework legislation, the norm of which should launch a mechanism for facilitating movement of goods between Ukraine and the EU and establish the conformity of national transit procedures with the European standards stipulated in the provisions of the conventions.

But, as noted in the report, in the past, namely in 2012, by the State Customs Service of Ukraine already were adopted the number of subordinate regulatory acts aimed at regulating detailed procedures in this area. Therefore, the adaptation of the Ukrainian legislation on the conformity of the forms of the uniform administrative document applied in the customs sphere to the norms of conventions began to take place long before the Association Agreement was signed, although it needs to be improved.

According to the revised European Neighborhood Policy in Brussels, on November 7, 2018 the report was published and the state of fulfillment of Ukraine's obligations under the Association Agreement between Ukraine and the EU was exposed [18].

As a whole, as of January 1, 2018, 29\% of Ukraine's commitments on approximation of customs legislation in the EU law were fulfilled.

The report states that, despite the stabilization of the economy achieved in recent years, the Ukraine continues to rely on international financial assistance (including the International Monetary Fund (IMF) and the macro-financial assistance program of the EU to maintain its macroeconomic stability.

As for customs matters and trade facilitation, the Ukraine lags behind the timetable for fulfilling its obligations to accede to the Conventions on the common transit procedure and the facilitation of trade in goods. The legislation of the Ukraine aimed at approximating the EU customs legislation, in particular bills on the authorized economic operator, the procedure for joint transit, the observance of intellectual property rights and customs assistance for travelers with the EU, the rules still have to be adopted by the Government.

Thus, there is a systemic dysfunctional feature, which is connected with the implementation of internal strategies in the customs sphere, and with the fulfilment of obligations at the level of international agreements. Robert C. Merton, in relation to the research of systems, noted: "The concept of dysfunction, which implies the notion of deformation, stress and strain at the structural level, provides the necessary analytical approach to the study of the dynamics and content of changes" [19]. 
Government administration without mistakes is practically impossible. Among the factors contributing to such mistakes should be the lack of proper control in the system of government administration, violation of the requirements of transparency of government administration, and many others. [12]

There are grounds to believe that there are reasons that, along with those are not subject to public discussion, have an origin related to the quality of the execution of current tasks during the performance of customs affairsby income and fee bodies.

An objective assessment of the current condition of the performance of state customs affairscan be considered the conclusions offered in the Report on the results of the audit of the effectiveness of the execution by the bodies of the State Fiscal Service of Ukraine of powers in the field of state customs affairsand fight against offenses during the application of customs legislation, approved by the decision of the Accounting Chamber of May 30, 2017 No 12-3 [20].

The Audit of the Account Chamber among the most urgent issues related to the execution ofobligations in reference to the performance of customs reforms, modernization and innovative development of customs in Ukraine has identified among others and those that converged with the concept of differentiation of customs issues in the relevant categories of attention: legal, organizational -structural, technological, communication.

1. The imperfect customs legislation is recognized. The normative-legal promotion in the field of state customs affairsin the period, that have been checked (from 2015 to the first quarter of 2017) is uncoordinated, does not facilitate the acceleration of customs clearance of goods, improvement of the administration of customs payments and simplification of customs formalities.

2. There is no cooperation between State Fiscal Service territorial bodies and law

enforcement authorities, provided by the Customs Code of Ukraine.

3. The activity of State Fiscal Service bodies in the control of compliance with customs rules by foreign economic entities was also ineffective, which did not contribute to minimizing violations within the scope of this sphere.

4. Legislative uncertainty of the procedure of the customs postaudit and, therefore, the formal approach when conducting documentary checks on the implementation of customs legislation by the subjects of foreign economic activity, gave grounds for receiving the state budget only $5.1 \%$ of the amount of monetary obligations for customs payments.

As stated in the Report, the structural divisions of internal audit of the bodies of State Fiscal Service prepared recommendations based on improving the normative-legal basis, increasing the level of control, taking measures of organizational nature. However, some recommendations have not been executed;there have also been frequent transposition of terms or formal execution of them, which had a negative influence on their effectiveness.

From this there is a possible assumption that, as regards the inertial regression process, it is "incapable from realistic positions to solve problems, caused by external circumstances and internal conflict" [21], which is the lack of proper vertical management of customs affairsin Ukraine.

To date, the decision has been made and the Ministry of Finance of Ukraine has been authorized to prepare and carry out measures for the reorganization of the fiscal service with the allocation of the customs direction to a separate service.

In this sense, the assumption that "pendulum solutions arise when the real problem behind them is not yet defined or they do not want to solve it. Then they resort to purely structural manipulations (to unite - to separate, to centralize - to decentralize, etc.) "[22], which is quite objectively related to the customs sphere. 
In the modern world, the uncertainty of the internal processes of any state is automatically translated into many-sided international ratings that influence on the image of the state in the world. One of the most important is the KOF Globalization Index.

Project managers established in 2002 at the Swiss Economic Institute and the Swiss Federal Institute of Technology identify globalization as a process, that destroys national boundaries, integrates national economies, cultures, technologies and management. The index includes variable indicators that measure the political, economical and social aspects of globalization.

During the period covered in the materials of this article, in accordance with globalization index of the Ukraine in the course of 2015-2018 ranked among the rest countries of the world as follows: [23]

$\begin{array}{lllll} & 2015 & 2016 & 2017 & 2018 \\ \text { General Index of Globalization } & 42 & 41 & 45 & 49 \\ \text { Economic globalization } & 56 & 54 & 63 & 89\end{array}$

No other goal has found strong support than economic growth [24].

The society as a consumer of the information product that it has to be the mass media and

differentstructures and organizations in the format of maintaining a standard view of customs activities as destructive does not receive sufficient, potentially objective conception about customs activities of the country.

As indicators of any processes of modernization and reforming are always the results, indicators of activity at the respective sphere. For customs, the indicators include not only expert international and national ratings, but primarily indicators of activity, which are determined by customs statistics and foreign trade statistics.

The growth trend of fiscal revenues every year is gaining ratesand creates conditions only for finding ways to increase the funds to be paid by the subject of foreign economic activity to the state budget to provide expenditures on the government's social and state programs.

The customs payments in 2017, transferred by the customs amounting to 303.8 milliards UAH made in sum more than $40 \%$ of total tax revenues. The aggregated performance indicators of the revenue and expenditure authorities quite clearly show the real state of fiscal achievements, which to a certain extent are ensured by the use of administrative measures and the appropriate management style.

According to data from the statistical information and reports on the activity of State Fiscal Service of the official portal State Fiscal Service [25], the steady growth of the state budget revenues comes from on the backdrop of negative balance of foreign trade over the past four years. At the same time, the weight of the exported product with the status of Ukrainian, more than twice exceed the weight of imported goods in Ukraine.

Estimated value of one ton of export is almost three times lower than the value of one ton of import. Against the background of growth of the transferred amounts of customs payments to the state budget, the tax loading, as a criterion for the efficiency and completeness of payment of customs payments, for four years continuously decreases.

The negative dynamics are economic instability and imbalance of internal processes in the country, the existence of contraband sources and the presence of a corrupt component in the activities of the revenue and expenditure authorities, it is not hard to admit it.

From this, less and less effort is being made to solve the problems connected with the conduct of planned reforms, the execution of strategic tasks, which are updated from time to time but are not being implemented. 
The strategy deals not so much with uncertainties as with unknown factors. These events involve so many variables and their various combinations that the prediction of the final result of their interaction is do not force for anyone.

The Logic suggests: it is necessary, with the preservation of flexibility and taking into account the experience gained, to move from general ideas to increasingly specific positions and tasks [26].

At the end of November 2018, by the experts of the Institute for Economic Research and Policy Consulting during the organization of the round table "Customs work by the eyes of the public" was presented the new advisory work "Public Monitoring of the Customs Authorities: Conclusions and Recommendations" [27].

The experts of Institute, taking as the basis such monitoring and a national survey of exporters and importers, formulated recommendations for improving of passage of customs procedures and promoting international trade. Among the main recommendations are interpreted together with past recommendations regarding the improvement of customs procedures, the introduction of modern technologies, the implementation of the institution of the authorized economic operator, reporting and transparent procedures for determining the customs value and classification of goods, improving the image and motivation of the customs officer, the introduction of effective procedures and mechanisms of postcustoms audit.

In the Public recommendations was formed the conception of the state of the fulfilment of the presented projects of customs reforms and issues whose themes remain unchanged for the long time. As noted by A. Prigozhin in the work "Disorganization", the reasons for the persistent failure of achievement of goals are that if an organization for some understandable reasons is not always able to achieve its goals, or this achievement is significantly complicated (at expense, in time, for completeness), that is why in it occurred a pathology that has to be revealed and overcome [22].

Customs affairs in Ukraine went to level of legislative administrationat the full scope of the principle of "Single Window" and the improvement of technical capabilities to simplify customs procedures, which became a definite achievement of the current period of its evolution. Instead, the automation of customs clearance, the application of blockade in the field of international trade and customs control, risk management on the ground of big data, the application of scanners with artificial intelligence systems, long-distance access to enterprise accounting systems, electronic examinations, unmanned drone that can expose the ships, which departed from the course for possible loading of illegal goods, these are institutes that are being introduced and are constantly being improved in the developed countries [28].

\section{Conclusions}

In view of the credible, competent sources, one may conclude that the balance of interests of the triad - government, business, society - is capable of ensuring the country's main goal integration and positioning at the level of the developed state.

The reform of the state customs affairs, as one of the planned Strategy of Ukraine - 2020, provides at its level the precondition for implementation through the prism of a social contract between the parties, where power, business and civil society have their own limits of responsibility.

Conducting of the reforms is a top priority task and the authorities are responsible for their carrying out. Moreover, control over the authority isa zone of responsibility of public society. 
Public responsibility, information research and public expertise are formed under the influence and based on sources of retransmitting and information and communication institutions, normative-legal support.

The continuum of such influences is placed in the range between the "society of mature citizens" and the civil responsibility and has personal characteristics, since it provides for a high level of economic, social, spiritual, political culture; developed legal relations; the interaction of free citizens with the state for the common good; self-organized society [29].

An in-depth analysis of the causes and consequences of overcoming the accumulated uncertainties and inconsistencies in the development of the state customs affairs, which require immediate intervention, is possible provided that to whole chain stakeholders of national customs affairs, thepersons who have experience and professional competence in customsaffairs, professional competence and a high level of social and political culture.

This will solve the problems faced by the world's customs administrations and, accordingly, the Ukraine, to propose the goals and identify the ways to achieve them in the shortest possible time, with minimal resource capacities and costs, and effective means of providing them.

The contradiction at the certain stage is a peculiarity of the innovative processes. Diversification of the strategies and programs of the transformation of the national customs affairs can be considered at the present stage, as a process of knowledge and learning, and in a synergistic approach involving authority, business and civil society capable for the satisfaction of public expectations and increasing external ratings.

\section{References:}

1. NortDuglas N-23 Instituty, institutsional'ny yeizmeneniya i funktsionirovaniye ekonomiki Per. s angl. A.N. Nesterenko; predisl.inauch. red. B.Z. Mil'ner. - M.: Fond ekonomicheskikhknig «Nachala», 1997. - 180 s. - (Sovremennaya institutsional'no-evolyutsionnaya teoriya) ISBN 0-521-39416-3 (angl., Pereplet) ISBN 0-521-39734-0 (angl., Myagkayaoblozhka) ISBN 5-88581-006-0 (rus.)

2. Strategicheskiye i roznichnyye proyekty State Fiscal Service do 2020 goda. Retrieved from:http://sfs.gov.ua/data/files/218923.pdf

3. Ugolovnyy komitet po delam Ukrainy, Yevropeyskogo Soyuza i Ukrainy. / $984 \_011$

4. Institutsional'nyye problemy ukrainskikh podkatovykh sistem i shlyapok??? AnaliticheskoyRozy, 2015. Retrieved from: https://rpr.org.ua/uploads/files/source/Policy_Tax_Reform_RPR.pdf

5. Reformirovat' $v$ Ukraine: rezhimraboty. Retrieved from: http://icps.com.ua/nashi-proekty/analityka/reformy-v-ukrayini-ekspertyza-pryynyatykh-derzhavnykh-rishen/

6. Drogovoz Y.U. Yak ta navsegda reformirovat' Gosudarstvennuyu sluzhbu Ukrainy /: Yuliya Drogovoz; Denis Cherníkov. - K .: Êvropeys'kiy ínformatsíyno-doslídnits'kiy tsentr, 2015. - 24 s.

7. Ugoda pro Koalítsíyu deputatskikh fraktsiy yevropeys'ka???Ukraïna» Ugoda Verkhovnoy Rady Ukraíni; Reglamentot 27.11.2014. Retrieved from: http://zakon.rada.gov.ua/laws/show/n0001001-15

8. Proshloye planetnogo zakhoda $\mathrm{v}$ viktorianskuyu programmu razvitiya kabrioletii Ukrainy i strategii razvitiya rozvitki «Ukraína-2020» v 2015 godu Rouz Rozporyadzhennya Kabinet Ministrov Ukrainy; Plan, Zakhodiot 04.03.2015 № 213-r. Retrieved from: http://zakon.rada.gov.ua/laws/show/213-2015-\%D1\%80

9. Mínísterstvo fínansív Ukraíni, List ot 27.09.2016 r. № 31-11000-07-10 / 27318

10. Proskhvalennya Kontseptsii zaluchshuyuzhizn' (radost') doreformirovaniya mitinga Derzhavno-sluzhashchikh, RozporyadzhennyaKabinetMinistrovUkrainy; Kontseptsiiot 11.02.2016 № 267-r. Retrieved from: http://zakon.rada.gov.ua/laws/show/267-2016-\%D1\%80

11. Mínísterstvo fínansív Ukraíni. Reforma State Fiscal Service. Retrieved from: https://www. minfin.gov.ua/news/organi-v-kompetencii-mfu/reforma-State Fiscal Service

12. Ponkin I.V. Teoriya deviantologii gosudarstvennogo upravleniya: Neopredelonnosti, riski, defekty, disfunktsii i provaly v gosudarstvennom upravlenii / IGSU RANKhiGSpriPrezidente RF / Predisloviyed.yu.n., prof. A.B. Zelentsova. - M .: Buki-Vedi, 2016. - $250 \mathrm{~s}$. 
13. Porter Ye. Mayk1 P60 Konkurentnaya strategiya: Metodologiya analiza rynkov i konkurentov / Maykl Ye. Porter; Per. s angl. - M .: Al'pina Biznes Buks, 2005. - 454 s. ISBN 5-9614-0143-0

14. Kunêv, YU.D. Upravlennya v mitingesluzhb: Pídruchnik: Za zag. red. YU.D. Kunêva / YU D Kunêv. - K .: Tsentrnavchal'noí líteraturi, 2006.

15. Dzhonston M. Nadlezhashcheye upravleniye: verkhovenstvo zakona, prozrachnost' I otvetstvennost' [Khorosheyeupravleniye: verkhovenstvozakona, prozrachnost'ipodotchotnost'] .- 32 str. Retrieved from:http://unpan1.un.org/intradoc/groups/obshchestvennosti / dokumenty / OON / unpan010193.pdf

16. Yevropeyskaya strategicheskaya Ukraina: Karta strategicheskogorozygrysha v 2017 godu - 2021.- 32 . Retrieved from: http://me.gov.ua/Documents/Detail?lang=uk-UA\&id=e6ab10fa-0ad9-4fe4-b8be-32f570693b64\&title = EksportnaStrategiiaUkraini-DorozhniaKartaStrategichnogoRozvitkuTorgivli2017-2021.

17. Sistema monopol'nogo vedeniya biznesa v Ukraine. Retrieved from: https: //www.kmu.gov.ua/ ua/diyalnist/yevropejska-integraciya/vikonannya-ugodi-pro-asociaciyu/zviti-nyav -ugodi-proasociaciyu

18. Rabochiy dokument sovmestnogo sotrudnika Otchet o realizatsii Assotsiatsii v Ukraine Bryussel', 7.11.2018 SWD (2018) 462 final. Retrieved from: https://cdn3-eeas.fpfis.tech.ec.europa.eu/cdn/farfuture/aZnrbQ70ZJtiXaRXV69qTtPI d-gbCzZxpirQUpU6EY / vremyaizmeneniye: 1541749617 / sayty / YESVDA / fayly / 2018 association_implementation_report_on_ukraine.pdf

19. Merton R.K. Sotsial'nayateoriyaisotsial'nayastruktura. - N'yu-York: S̄ōobodnayapressa, 1968. - 702 s. - S. 107.

20. Kakovy rezul'taty revizii effektivnosti vikonnskogo ispol'zovaniya Gosudarstvennoy sluzhby zdravookhraneniya Ukrainy, v rezul'tate kotoroy voznikli problemy, svyazannyye s soblyudeniyem norm pravosudiyaIsotsial'noyzashchity?

21. Velikiyt lumachniy slovar' suchasnoí ukraíns’koí movy. - “Perun”. 2005.

22. Prigozhin A. I. P75 Dezorganizatsiya: Prichiny, vidy, preodoleniye / A.A. I. Prigozhin. - M .: Al'pina Biznes Buks, 2007. - 402 s. - (Seriya «Sinergichnayaorganizatsiya»)

23. Indeks globalizatsii KOF. Retrieved from:https://www.kof.ethz.ch/en/forecasts-and-indicators/indicators/kof-globalisation-index.html

24. GelbreytDzh. K. Novoye industrial'noye gosudarstvo. Dzhon Gelbreyt. Novoye industrial'noye obshchestvo. Perevodnarusskiyyazyk: L. YA. Rozovskiy, YU. B. Kochevrin, B. P. Likhachov, S. L. Batasy. - M., 2004. // Elektronnayapublikatsiya: Tsentrgumanitarnykhtekhnologiy. - 29.03.2012. Retrieved from: https://gtmarket.ru/laboratory/basis/502

25. Derzhavna fiskalna sluzhba Ukrayiny Ofitsiynyy portal. Retrieved from: http://sfs.gov.ua/

26. Henri Mintsberh, Dzheyms Brayan Kuinn, Sumantra Hoshal Stratehichnyy protses Kontseptsiyi, problemy, rishennya. Retrievedfrom:http://bigc.ru/theory/books/gmsp/c_2.php

27. IED prezentuvav 13 rekomendatsiy dlya pokrashchennya mytnykh protsedur v Ukrayini. Retrieved from: https://goo.gl/WSTmyK

28. Retsepty dlya Ukrayny. Kak tekhnolohyy yzmenyat tamozhnyu. Retrieved from: http://ses-help.org.ua/articles/24556/

29. Drahomyretska N. Hromadyanska vidpovidalnist yak viddzerkalennya rozvytku hromadyanskoho suspilstva / N. Drahomyretska, I. Matvyeyenko // Visnyk Natsionalnoyi akademiyi derzhavnoho upravlinnya pry Prezydentovi Ukrayiny. - 2009. - Vyp. 1. - S. 257-268. Rezhym dostupu: http://nbuv.gov.ua/UJRN/Vnadu_2009_1_34

30. Regulation (EU) No 952/2013 oftheEuropeanParliamentandoftheCouncilof 9 October 2013 layingdowntheUnionCustomsCode. Retrieved from: https://eur-lex.europa.eu/legal-content/EN/ TXT/?uri=CELEX\%3A32013R0952 


\section{ДИВЕРСИФІКАЦІЯ СТРАТЕГІЧНИХ ПРОГРАМ ТРАНСФОРМАЦІЇ МИТНОЇ СПРАВИ В УКРАЇНІ: ЗАПОРУКА РЕАЛІЗАЦІЇ ЧИ ДЕСТРУКТИВНА ПЕРСПЕКТИВА}

\section{Ірина КВЕЛІАШВІЛІ,}

Університет митної справи та фінансів, Україна

Митна діяльність є об'єктом суцуільного інтересу в Украӥні. Стейкхолдери та ті, щуо зацікавлені у обговоренні рейтингів, формуванню іміджу митниці підтримують рівень цих інтересів. У статті розглянуті концептуальні питання імплементаціїі та виконання домовленостей по митних питаннях Угоди про асоціацію України з СС, стан їх виконання, а також основні акценти презентованих стратегій реформування державної митної справи. Висновки моніторингу виконання Угоди про асоиіацію, експертизи громадських організацій, дані статистики міжнародної торгівлі надали підстав дійти висновків, щэо шлях пошуку оптимальної стратегї цее не період часу, а лише професійний підхід, поміркованість ијілей, синергетичність прагнення та участі державних інститутів у задоволенні суспільних очікувань.

Зроблено висновок, що поглиблений аналіз причин та наслідків подолання накопичених невизначеностей та неузгодженостей аспектів розвитку державної митної справи, які потребують негайного втручання, можливий за умови залучення до всього ланцюга стейкхолдерів національної митної справи осіб, щзо мають досвід та професійну компетентність у митній справі, професійну ерудииію та високий рівень соиіальної та політичної культури. Це дозволить вирімувати проблеми, щзо постають перед митними адміністраціями світу та, відповідно, України, ставити цілі та визначати шляхи їх досягнення у найкоротший термін, з мінімальними ресурсними навантаженнями та витратами, ефективними засобами їх забезпечення.

3 метою обгрунтованого викладення матеріалів у статті застосовувались діалектичний, системний, дедуктивний методи дослідження, щчо надало більш повного розуміння інституційних прочесів, щзо відбуваються в митній сфері.

Ключові слова: стратегія, стратегічні цілі, державна митна справа, реформи, трансформація, моніторинг, експертиза, громадськість. 